\title{
THE POLLEN SPECTRUM OF THE HONEY OF TETRAGONISCA ANGUSTULA ANGUSTULA LATREILLE (APIDAE, MELIPONINAE) ${ }^{1}$
}

\author{
Satoko IWAMA ${ }^{2}$, Therezinha S. MELHEM \\ Instituto de Botânica, Caixa Postal 4005, São Paulo (Brasil)
}

\section{SUMMARY}

Those honeys which were microscopically analysed presented a reasonably large number of pollen forms - a total of 55 in 23 samples. The pollen spectrum analysis of two colonies observed indicated that the bees from these colonies were attracted by the same floral supplies, though in different places, at a distance of around 140 meters from one another. The majority of the pollen grains were classified as isolated pollen. In the dominant pollen class were included: Alchornia triplinervia, Eucalyptus robusta, Petroselinum hortense and Schinus terebinthifolius. Included among the plant species classified as accessory pollen yielders were, for example: Bidens sp., Byrsonima intermedia, Caesalpinia peltophoroides, Dalbergia sp., Eucalyptus rudis., E. tereticornis, Euphorbia splendens, Mimosa daleoides, Piptandenia rigida, Sorocea bonplandii and Trema micrantha.

Found as isolated pollen yielders were, for example: Ambrosia sp., Brassica campestris, Chenopodium sp., Jasminum azoricum, Leucaena glauca, Mangifera indica, Phy'llanthus sp., Struthanthus andrastylus, Tipuana tipu, etc.

\section{INTRODUCTION}

The earliest microscopic studies of honey were made by PFISTER (1895); these suggested the possibility of determining the geographical origin of the honey from the pollen contained therein (Louveaux, 1968; Louveaux et al., 1970; Maurizio, 1975). It was, however, from 1930 onwards that the interest in microscopic investigation of honey increased (Maurizio, 1975).

1. This study was carried out with the financial support of the Conselho Nacional de Desenvolvimento Cientifico e Tecnologico $(\mathrm{CNPq})$ and the Fundação de Amparo à Pesquisa do Estado de São Paulo (FAPESP).

2. Biology student-teacher of the Instituto de Botânica, on a scholarship from FAPESP. This report constitutes part of a Master's Thesis, entitled " Food collecting and honey quality of Tetragonisca angustula angustula Latreille (Apidae, Meliponinae) defended at the Instituto de Biociencias da Universidade de São Paulo, under the supervision of Prof. Dr. Paulo Nogueira Neto. 
From qualitative analysis of pollen grains it becomes possible to determine the botanical species that make up the pollen spectrum of honey samples. The pollen spectrum shows whether the honey samples are from different geographical and floral regions, and also the flowering time of the bee plants and their value as nectar and pollen suppliers.

Through quantitative analysis of the pollen grains, it is possible to establish the proportion which each plant, as a nectar supplier contributes, to the constitution of the honey. However, this proportion depends on the abundance of anthers, on the pollen, and on the structure and biology of the different plant species.

The few existing pollen analyses of Brazilian honeys were made by SANTOS (1961, 1964, 1974), who studied the pollen grains in a series of samples collected from the hives of Apis mellifera in São Paulo State, and also by BARTH (1970 a, b, c, d, e, 1971) who studied honey samples of Apis mellifera from different regions of Brazil. As regards the stingless bees (Meliponinae), ZANDER (1935, apud BARTH, 1970 a) analyzed honeys of South America, especially Brazil, and MAUrizio (1964, apud BARTH, 1970 a) studied five samples of honey from meliponine bees.

With reference to nectariferous and polliniferous Brazilian plants useful to $A$. mellifera, little is known, even though some researchers - AMARAL (1953, 1970), KERR and Amaral (1957), Santos (1961), Campêlo (1972), Giorgini and Gusman (1972), Juliano (1972), KERR (1972) - have identified various species of melliferous plants frequented by Meliponinae, Nogueira-Neto (1953) referred to several species to stingless bees. Ros (1952) identified various plants of apicultural interest, from Cuba and Tropical America respectively, and especially from Brazil. As regards plants frequented by Meliponinae, Nogueira-Neto (1953) referred to several species visited by these bees for the purpose of collecting nectar and pollen grains.

From among the stingless bees we chose Tetragonisca angustula angustula Latreille (jatai), because it is one of the commonest bees in the city of São Paulo; it is easily bred, and it adapts itself to different nesting conditions, such as hollows in stone walls, hollows in trees, inside light-fittings, etc. There is also the fact that these bees produce clear, tasty honey Nogueira-NETO, 1970), with therapeutic attributes in the treatment of eye and lung conditions.

\section{MATERIAL AND METHODS}

\section{Material}

Fig. 1 shows the location of colonies A and B used in the present studies. Colony A was kept in the Bee Laboratory of the Zoology Department, Biosciences Institute, São Paulo University, in an observation hive of the SaKagami type, modified by Nogueira-Neto (1970). Colony B was put in a rational hive designed and built by NoGUeiRA-NeTo (1970) and kept in the orchid garden of the Botany Department, in another part of the same Institute. 




FIG. 1. - Partial plan of the University Campus, São Paulo, showing the localization of the Biosciences Institute, University of São Paulo, and the hives of $\mathrm{T}$. angustula (* A. colony $A,{ }^{* *} B$. colony $B$ ). 


\section{Methods}

While this study was in progress, colony A became weak, and sometimes received additional food such as sugar syrup composed of one part of water to two of saccharose.

\subsection{Honey collection}

In general, samples were taken weekly from colonies $\mathrm{A}$ and $\mathrm{B}$, between 10 and 11 o'clock, a.m., using a sterilized glass pipette of approximately $4 \mathrm{~mm}$ internal diameter, and about 0.5 grams of honey was put in glass receptacles. A thymol crystal was added to each sample to avoid probable fermentation; afterwards the samples were kept in a freezer at a temperature of about $-10^{\circ} \mathrm{C}$.

\subsection{Collection of reference material}

The reference material consisted of microscope slides containing pollen grains prepared from the anthers of plant species visited by $T$. angustula and/or from anthers of herbarium specimens, obtained from the Herbarium of the Institute of Botany, and shown to be melliferous by the various authors already cited.

The jatai forages with greatest intensity between 11 a.m. and 2 p.m. For this reason the plants frequented were observed, in the surroundings of the Botany Department, between these hours; flowering branches were then collected for subsequent pressing and drying and botanical identification. Before pressing and drying the material, anthers were removed from at least two flowers and fixed in glacial acetic acid.

\subsection{Preparation of slides} 1960).

In the study of pollen grains for the reference material the acetolysis method was used (ERDTMAN,

For extracting and mounting the pollen grains present in the honey sediment, the technique described by Louveaux et al. (1970) was adapted, in that the acetolysis technique was introduced as follows:

a. dissolve 3 to 4 grams of honey in twice the volume of hot distilled water $\left(45^{\circ} \mathrm{C}\right)$;

b. heat in a water bath for 5 minutes at $45^{\circ} \mathrm{C}$;

c. centrifuge for 10 minutes at $2500-3000 \mathrm{rpm}$;

d. remove the supernatant;

e. prepare the acetolysis mixture, sulfuric acid + acetic anhydride $(1: 9)$; about 5 millilitres of this mixture is put in each tube;

$f$. put the tubes with this mixture in the water bath, leaving them for about 2 minutes at $100^{\circ} \mathrm{C}$;

g. centrifuge the mixture, while still hot, for 10 minutes at $1000 \mathrm{rpm}$;

$h$. eliminate the supernatant;

$i$. wash the pollen residue in distilled water ( 10 millilitres) + alcohol (3 drops);

$j$. centrifuge and run off superficial matter again;

$k$. add to the tubes 5 millilitres of distilled water + glycerine $(1: 1)$, leave the material in this mixture for between 30 minutes and 24 hours;

$l$. centrifuge, remove the supernatant, and then leave the tube upwards; the material is now ready to be deposited on a slide;

$m$. agitate the sediment with a glass rod, and then deposit it on a microscope slide;

n. dry the sediment on a hot plate at around $35^{\circ} \mathrm{C}$;

$o$. mount in glycerined gelatine. Place the gelatine, with a diameter of about 2 millimetres, on the cover-slip, which is heated until the gelatine melts; then the whole is turned over on top of the slide and sealed with paraffin. The paraffin should be applied to one side of the cover-slip, on a hot plate, so that it penetrates by capillary action between the slide and the cover-slip surrouding the glycerined gelatine pre- 
paration which contains the pollen grains. Then turn the slide and cover-slip over on to a piece of filter paper. As the paraffin solidifies, the pollen grains still contained in the liquid gelatine are deposited on the cover-slip, thus facilitating observation.

\subsection{Pollen analysis of honey}

Initially, identification of material was carried out on the basis of the morphological characteristics used in palynotaxonomic keys, such as isolated grains and compound grains, types of opening, sculpture, shape and size of the pollen grains. These characteristics allow identification at family level and in many cases as far as the genus. For comparisons based on the reference preparations and on specialized bibliography, attemps were made to arrive at the identification to species level of the pollen grains present in the honey. Owing to the pollen homogeneity of some groups this identification was only possible as far as the genus, the family, or even the pollen type. After identifications, the next step was to find out the representative frequency of the species in the sample.

In each sample 500 pollen grains were counted, with the exception of the samples from colony B from $06 / 74$ and $10 / 74$, in which the counts were 134 and 108 pollen grains respectively.

The pollen grain counts were made using the first field chanced upon, and within this, counting all the existing pollen grains. The subsequent fields were obtained from the first by horizontal shifting of the slide.

The pollen grains counted in the honey were grouped into three frequency classes. MAURIzIO (1975) named as dominant pollen (D.P.) those species which represent more than $45 \%$ of the total pollen. The accessory pollen (A.P.) represents from 16 to $45 \%$, and isolated pollen (1.P.) from 1 to $15 \%$.

The pollen grains present in the honey, specially those which presented a higher frequency, were recorded by means of photomicrographs taken with a Karl Zeiss C- 35 camera coupled to a Karl Zeiss microscope $0,5 \mathrm{x}$ Tessovar $1 \mathrm{x}$, with movie camera $0,4 \mathrm{x}$ using a $40 \mathrm{x}$ objective, Optovar $1,25 \mathrm{x}$, and grey and blue coupled filters. All the photomicrographs were taken on Kodak film, Panatomic-X, ASA 32.

\section{RESULTS}

In general, the honey samples examined presented a large quantity of pollen grains (Fig. 2 and 3).

The results obtained refer to the samples taken in the months of $05 / 74$ to $05 / 75$; in $09 / 74$ the honey samples were not collected, as there was a small quantity of honey stored in colonies A and B. For the same reason, honey was not collected from colony $\mathrm{A}$ in $10 / 74$.

Fig. 4 represents the histogram of the frequency of 55 pollen forms found in the 23 samples analysed, where each column represents one of the forms identified, up to species, genus or family level or pollen type. Distribution on the graph follows alphabetical order, used also in Table 1, to facilitate the location of the pollen grains present in the honey. From the same figure it may also be noted that colonies A and B present, with rare exceptions, the same pollen forms and in very similar percentages, that is, the peaks are repeated in both colonies.

Among the predominant plant species in the honey from colony A - that is, those with a relative frequency of $50 \%$ or more - may be noted : Schinus terebenthifolius (Fig. 5), Ambrosia sp., Alchornia triplinervia (Fig. 6), Euphorbia splendens (Fig. 7), 


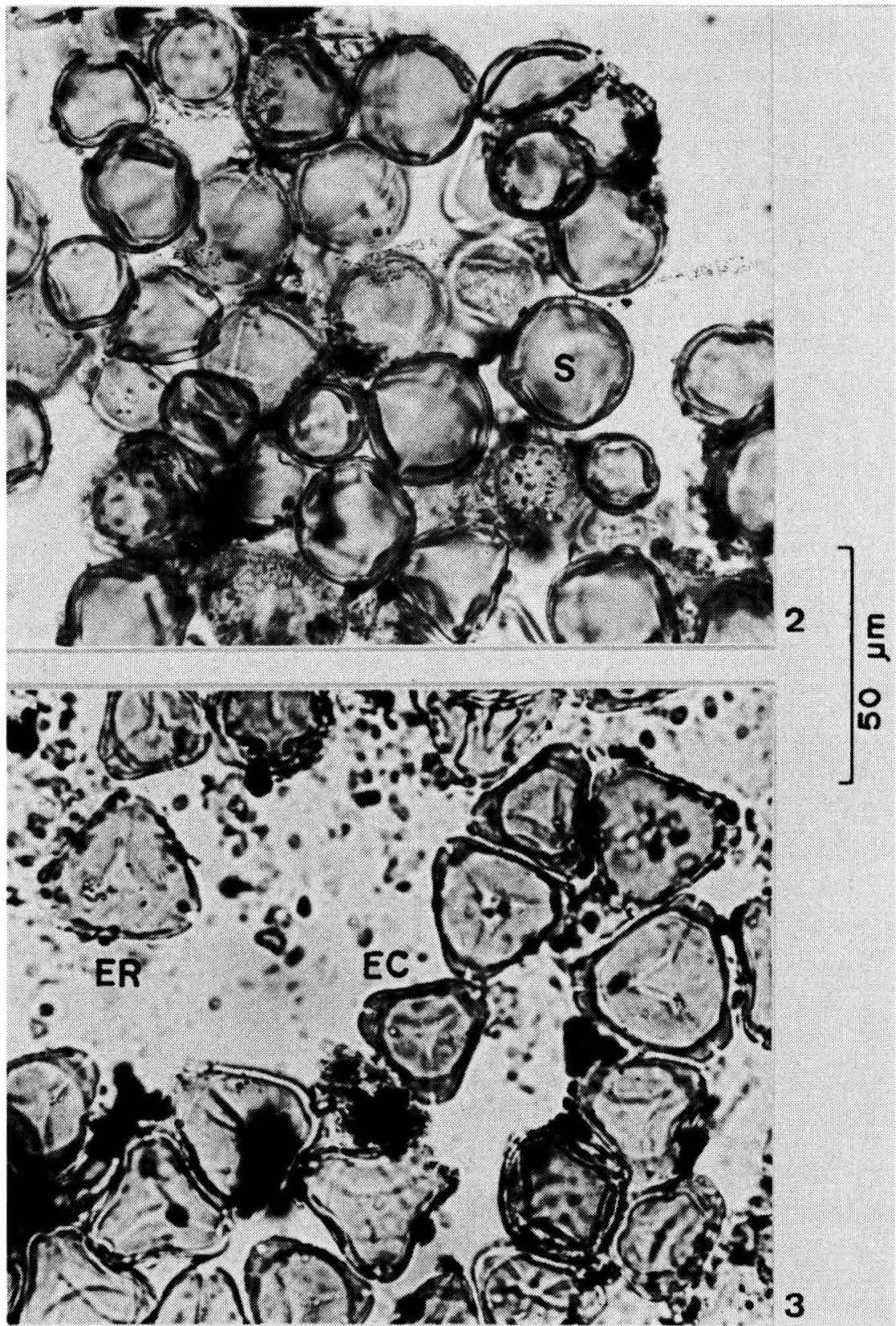

FIG. 2-3. - Photomicrographs showing the general aspect of the pollen grains in the honey of $\mathrm{T}$. angustula, distinguishing : Solanum $\mathrm{sp}_{1}(\mathrm{~S})$; Eucalyptus cinerea $(E C)$ and $E$. robusta $(E R)$. 

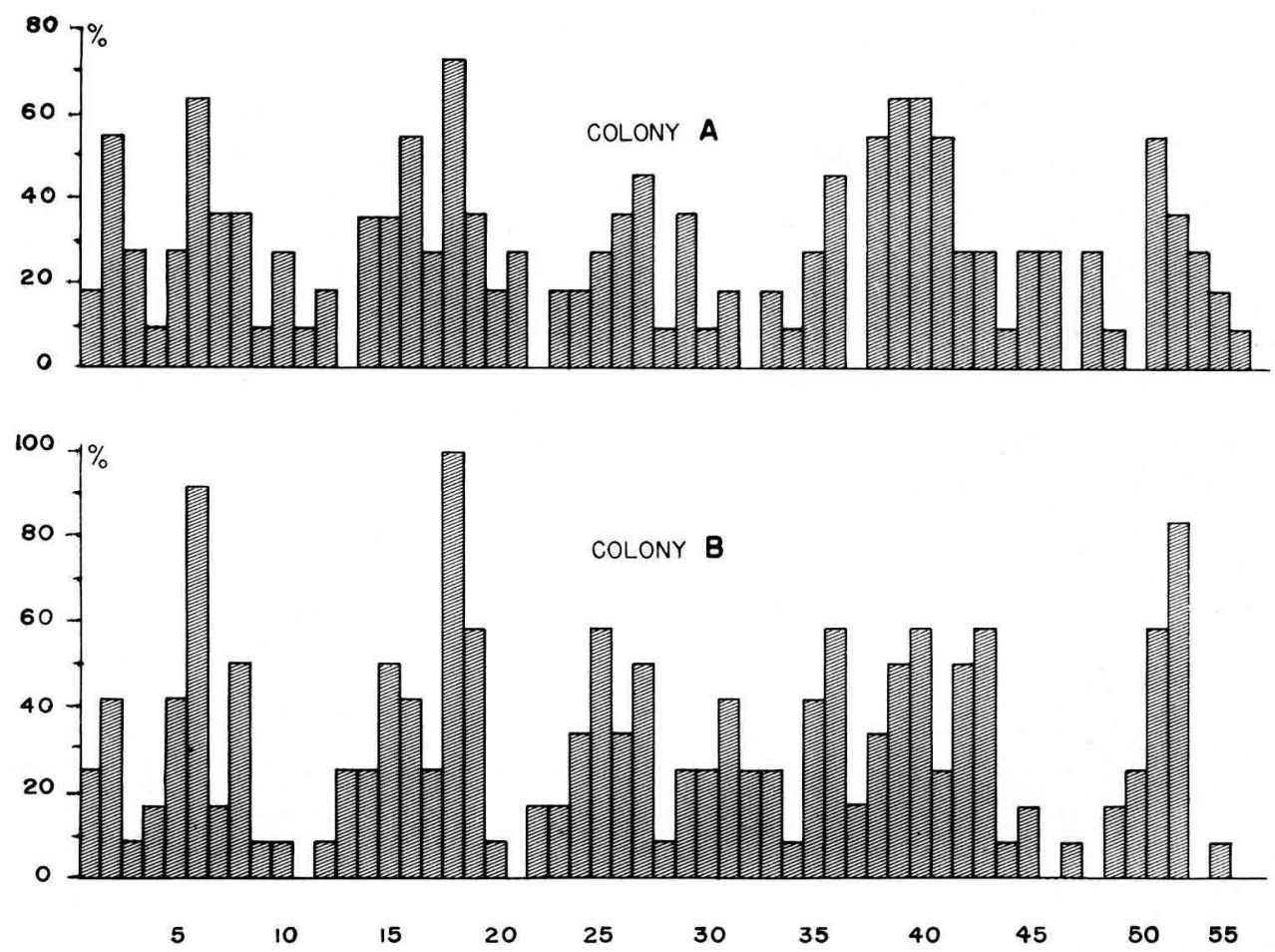

FIG. 4. - Frequency of the pollen grains from the different plant species present in the honey samples of $\mathrm{T}$. angustula :

ANACARDIACEAE 1. Mangifera indica, 2. Schinus terebinthifolius; ARALIACEAE 3. Tetrapanax sp; BALSAMINACEAE 4. Impatiens sultani; CHENOPODIACEAE 5. Chenopodium sp; COMPOSITAE 6. Ambrosia $\mathrm{sp}, 7$. Bidens $\mathrm{sp}, 8$. Mikania $\mathrm{sp}, 9$. Solidago $\mathrm{sp}, 10$. Wedelia paludosa, 11. Xanthium sp, 12. Compositae 1, 13. Compositae 2; CRUCIFERAE 14. Brassica campestris; CYPERACEAE 15. Cyperaceae 1; EUPHORBIACEAE 16. Alchornia triplinervia, 17. Euphorbia pulcherrima, 18. E. splendens, 19. Phyllanthus sp; GRAMINAE 20. Gramineae 1; LABIATAE 21. Hiptis sp, 22. Peltodon sp; LEGUMINOSAE 23. Caesalpinia peltophoroides, 24. Dalbergia sp, 25. Leucaena glauca, 26. Mimosa daleoides, 27. Piptadenia rigida, 28. Sophora tomentosa, 29. Tipuana tipu; LILIACEAE 30. Aloe sp; LORANTHACEAE 31. Struthanthus andrastylus; LYTRACEAE 32. Lagenstroemia indica; MALPIGHIACEAE 33. Byrsonima intermedia; MELASTOMATACEAE 34. Miconia sp, Tibouchina chamissoana; MORACEAE 36. Sorocea bonplandii; MYRTACEAE 37. Eucalyptus blakelyi, 38. E. cinerea, 39. E. robusta, 40. E. rudis, 41. E. tereticornis, 42. Eucalyptus sp; OLEACEAE 43. Jasminum azoricum; PROTEACEAE 4. Grevillea sp; ROSACEAE 45. Rosa sp; SAPINDACEAE 46. Cupania vernalis; SCROPHULARIACEAE 47. Pulownia tomentosa; SOLANACEAE 48. Solanum sp , 49. Solanum $\mathrm{sp}_{2}, 50$. Solanum $\mathrm{sp}_{3}$; ULMACEAE 51. Trema micrantha; UMBELLIFERAE 52. Petroselinum hortense; UNDETERMINED POLLINIC SPECIES 53. Type 1, 54. Type 2, 55. Type 3.

Eucalyptus cinerea (Fig. 3), E. robusta (Fig. 3), E.rudis (Fig. 8), E. tereticornis (Fig. 9), and Trema micrantha (Fig. 6 and 10).

In the honeys from colony $\mathrm{B}$, the following predominant species were found: Ambrosia sp., Cyperaceae 1 (Fig. 10), Mikania sp. (Fig. 11), Euphorbia splendens, Phyllanthus sp., Leucaena glauca (Fig. 12), Piptadenia rigida (Fig. 5), Sorocea bonplandii (Fig.6), Eucalyptus robusta, E. rudis, Eucalyptus sp., Jasminum azoricum, 


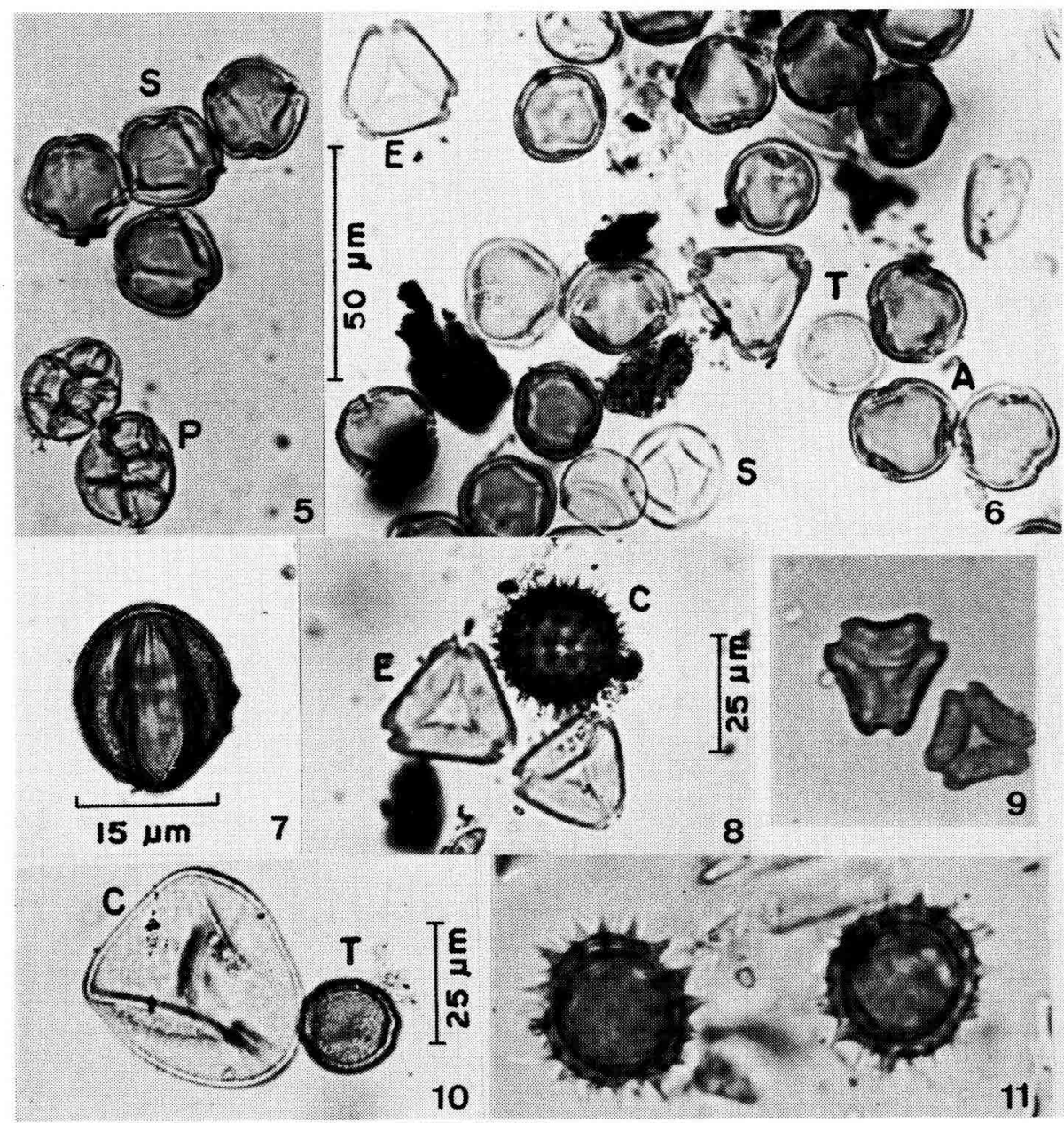

FIG. 5-11. - Photomicrographs of the pollen grains present in the honey of T. angustula Fig. 5 : Piptadenia rigida $(P)$, Schinus terebinthifolius $(S)$.

FIG. 6 : Alchornia triplinervia $(A)$, Eucalyptus blakelyi $(E)$, Sorocea bonplandii $(S)$, Trema micrantha $(T)$ Fig. 7 : Euphorbia splendens; Fig. 8 : Compositae 1 (C), Eucalyptus rudis (E).

FIG. 9 : Eucalyptus tereticornis; FIG. 10 : Cyperacea 1(C), Trema micrantha (T); Fig. 11: Mikania sp.

Trema micrantha and Petroselinum hortense (Fig. 12 and 13). In Eucalyptus sp., were included all the species of this genus which could not be determined.

Pollen grains from some plant species only occurred in colony A, such as Xanthinum sp., Hyptis sp., Cupania vernalis, Solanum sp. (Fig. 2 and 14), Type 1 (Fig. 14) 




FIG. 12-14. - Photomicrographs of the pollen grains present in the honey of $T$. angustula. FIG. 12 : Compositae I (C), Eucalyptus rudis (E), Leucaena glauca (L); Mimosa daleoides (M); Petroselinum $f$ hortense (P); Trema micrantha (T); FIG. 13 : Petroselinum hortense (P); FIG. 14 : Solanum $\operatorname{sp}_{1}(S)$; Type $1\left(\mathrm{~T}_{1}\right)$.

and Type 3, and others only in colony B, such as Compositae 2, Peltodon sp., Lagerstroemia indica, Eucalyptus blakelyi, Paulownia tomentosa and Solanum sp.

Table 1 represents the pollen spectrum of the honey samples examined. The majority of pollen grains present were classified as isolated pollen (I.P.), a few as acces- 


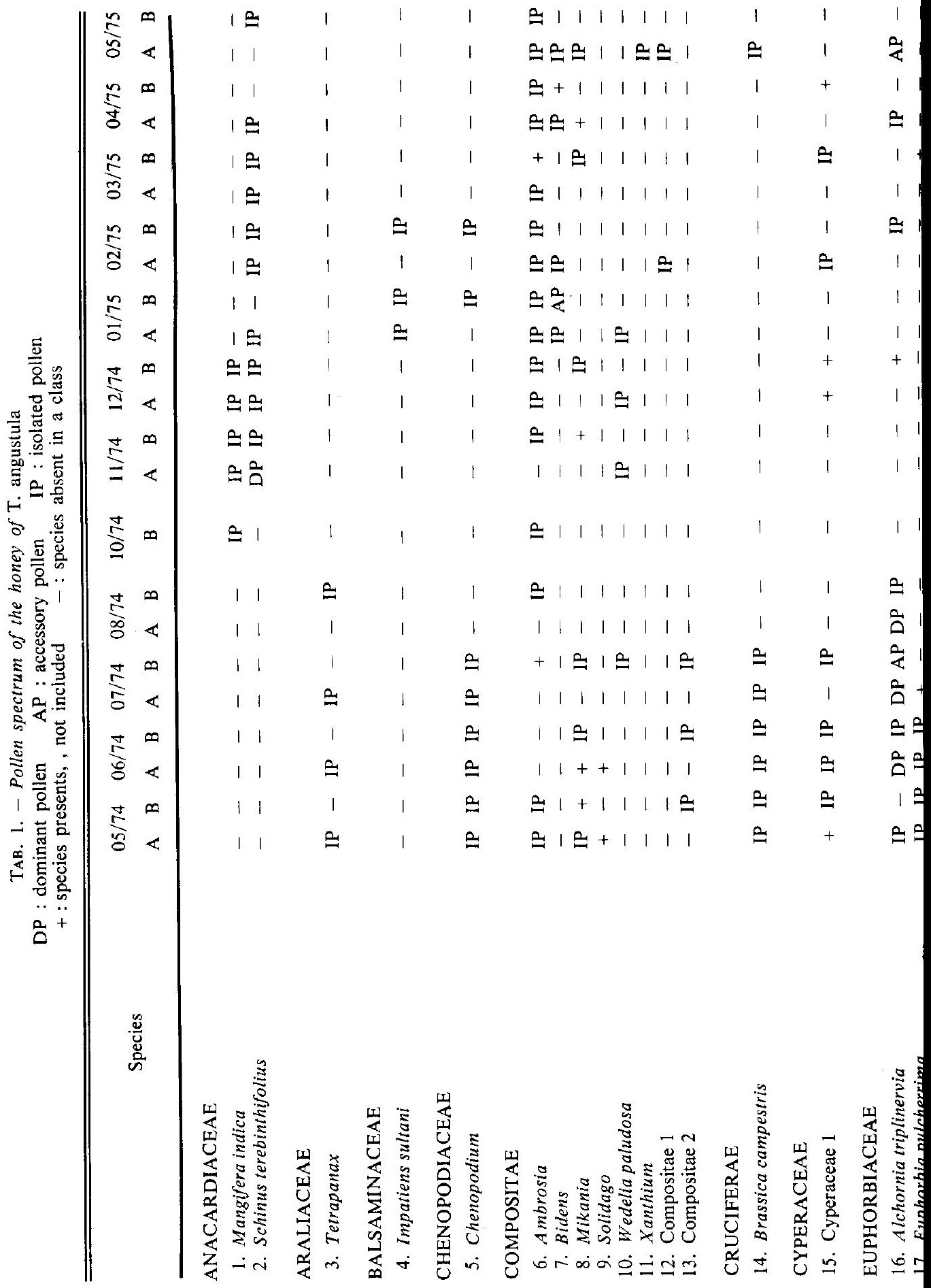




\begin{tabular}{|c|c|c|c|c|c|c|c|c|c|}
\hline 1 & 1 1 & | $1 \Xi \Xi \Xi 1$ & I & $\Leftrightarrow$ & I & I & 11 & $\theta$ & । 1 \\
\hline 1 & 11 & $\begin{array}{lllllll}1 & 1 & 1 & 1 & 1 & 1 & 1\end{array}$ & I & $\cong$ & 1 & 1 & 11 & 1 & $1 \cong$ \\
\hline 1 & 11 & $1 \mid ق 111$ & 1 & $\approx$ & । & । & 1 1 & 1 & $1 \Omega$ \\
\hline I & 11 & $\begin{array}{lllllll}1 & 1 & 1 & 1 & 1 & 1 & 1\end{array}$ & I & । & 1 & । & 11 & $\Leftrightarrow$ & 18 \\
\hline 1 & 11 & $1|\Theta| \Theta \mid$ & I & 1 & 1 & 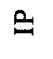 & $1 \cong$ & । & $1 \%$ \\
\hline B & 11 & $11+1111$ & 1 & 1 & 1 & 1 & $1+$ & 1 & । \\
\hline । & 11 & | 1 @ \& 1 & 1 & 1 & 1 & 2 & $1 \cong$ & $\Leftrightarrow$ & 온 \\
\hline 1 & $\because 1$ & | $1 \boxminus D \boxminus 1 \theta$ & 1 & । & 1 & $\&$ & $1 \%$ & 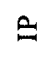 & $1 \Xi$ \\
\hline 1 & 11 & | 1 1 & 1 & 1 & 1 & $\cong$ & $1 \cong$ & 1 & | | \\
\hline 1 & 11 & 연영 & I & 1 & 1 & 1 & $1 \Leftrightarrow$ & । & । 1 \\
\hline 1 & 11 & | 11121 | & 1 & + & 1 & 1 & 19 & 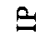 & 11 \\
\hline 1 & 11 &  & $\Leftrightarrow$ & । & 1 & $\Xi$ & 11 & I & 11 \\
\hline 1 & 11 & $\triangleq 1 \cong 1$ 回年 & 1 & 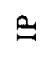 & 1 & 1 & 11 & 보 & 11 \\
\hline 1 & 11 & $1|1| \frac{2}{4}=0$ & 1 & । & । & 1 & 11 & I & 11 \\
\hline । & 11 & $\Leftrightarrow 12110$ & 1 & $\cong$ & 1 & 1 & 19 & 1 & 11 \\
\hline I & 11 & $1 \triangleq \triangleq \Xi 111$ & 1 & $\cong$ & 1 & 1 & 11 & 孚 & $\frac{2}{4} 1$ \\
\hline I & 11 & $1 E 1|1| 1$ & $i$ & + & 1 & 1 & 11 & $\frac{2}{4}$ & 11 \\
\hline 1 & 11 & $1 \Leftrightarrow 1 \Leftrightarrow 11$ & $R$ & $\cong$ & + & 1 & 11 & $\Leftrightarrow$ & 11 \\
\hline 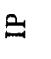 & $\because 1$ & $|\&| 1 \mid 1 \Xi$ & 1 & 1 & । & । & 11 & 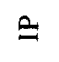 & 11 \\
\hline 1 & 1 을 & $1 \& 11$ & $\cong$ & । & 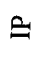 & 1 & 11 & 1 & 11 \\
\hline 1 & 11 & $1|1| \equiv 1+$ & 1 & 1 & 1 & 1 & $\approx 1$ & $\Leftrightarrow$ & 1 은 \\
\hline$\approx$ & $1 \cong$ & $1 ㅇ \mid=1$ 인 & $\Leftrightarrow$ & । & $\cong$ & 1 & +1 & + & $1 \frac{2}{4}$ \\
\hline I & $\Leftrightarrow 1$ & $111+111$ & 1 & 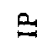 & 1 & । & 11 & 1 & 1 은 \\
\hline
\end{tabular}

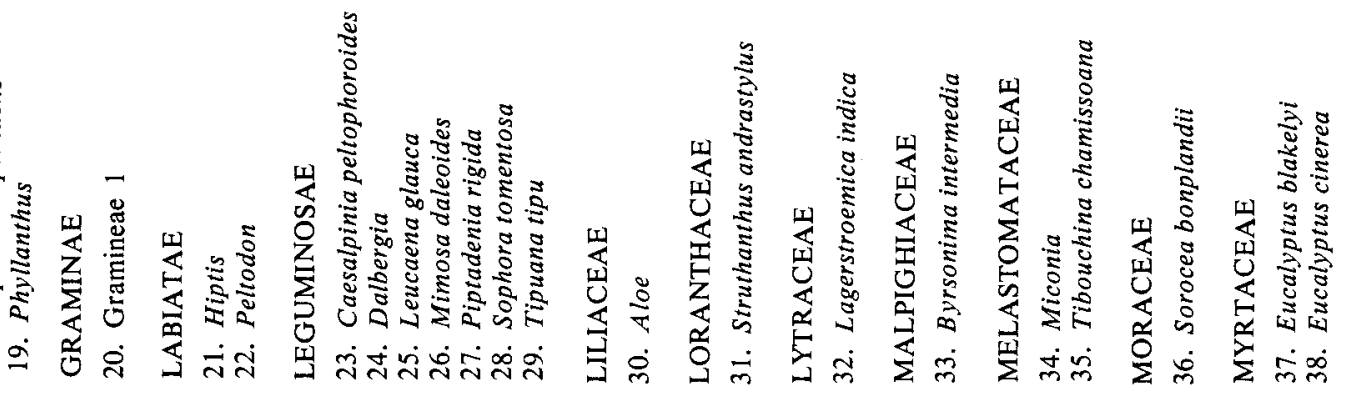







sory pollen (A.P.) and very rarely as dominant pollen (D.P.); the $(+)$ sign in the table means that a plant species occurred in the honey but was not included in a class as it did not appear in the microscope field at the moment of counting.

Colony A presented four plant species belonging to the dominant pollen class that is, they were present as more than $45 \%$ of the total pollen : Schinus terebinthifolius, Alchornia triplinervia, Eucalyptus cinerea and E. robusta; while colony B presented as dominant pollen Eucalyptus sp. and Petroselinum hortense. These pollen grains also appeared, with the exception of $S$. terebinthifolius and $P$. hortense, as accessory pollen.

The pollen grains grouped as accessory pollen in colony A were : Caesalpinia peltophoroides (Fig. 15) Mimosa daleoides (Fig. 16) Byrsonima intermedia (Fig. 17), Tibouchina chamissoana, Sorocea bonplandii, Eucalyptus tereticornis and Solanum $\mathrm{sp}_{1}$.

As accessory pollens, the following were found in colony B : Bidens sp., Euphorbia splendens, Eucalyptus blakelyi, Paulownia tomentosa and Trema micrantha. On the other hand, pollen grains from Dalbergia sp., Piptadenia rigida, Eucalyptus cinerea, E. robusta, E. rudis and Eucalyptus sp., occurred as much in colony A as in colony B.

Other pollen grains, existing in proportions not represented by either the dominant or accessory classes, were classified as isolated pollen, that is, present as less than $15 \%$ of the total pollen, such as for example: Bidens sp. (Fig. 18), Chenopodium sp. (Fig. 19), Euphorbia pulcherrima (Fig. 20), Aloe sp., Tipuana tipu (Fig. 21), Struthanthus andrastylus (Fig. 22), Tipo 2 (Fig. 15), etc., as shown in Table 1.

\section{DISCUSSION}

Many researchers are against the preparation of pollen grains in melittopalynology by the acetolysis method, arguing that this method modifies the size and eliminates entirely the natural colouring of the pollen grains; they also point out that the numerous manipulative stages involved in the method waste a good deal of time. These researchers use no preparation technique for the reference material; for the honey, their methodology follows that of Louveaux et al. (1970).

Acetolysis makes for better permanent slides of pollen grains, thus permitting more precise and more perfect observations. This technique for honey was employed by VIEITZ (1950) and SMITH (1965) and by SHARma (1970) with pollen loads collected by $A$. mellifera.

As regards the pollen grain count from a honey sample, VERGERoN (1964), demonstrated that, owing to the heterogeneity of the microscope preparations and the number of pollen grains from different species generally present in 10 or 20 grams of honey, it is necessary to identify at least 1,200 pollen grains to obtain a satisfactory 


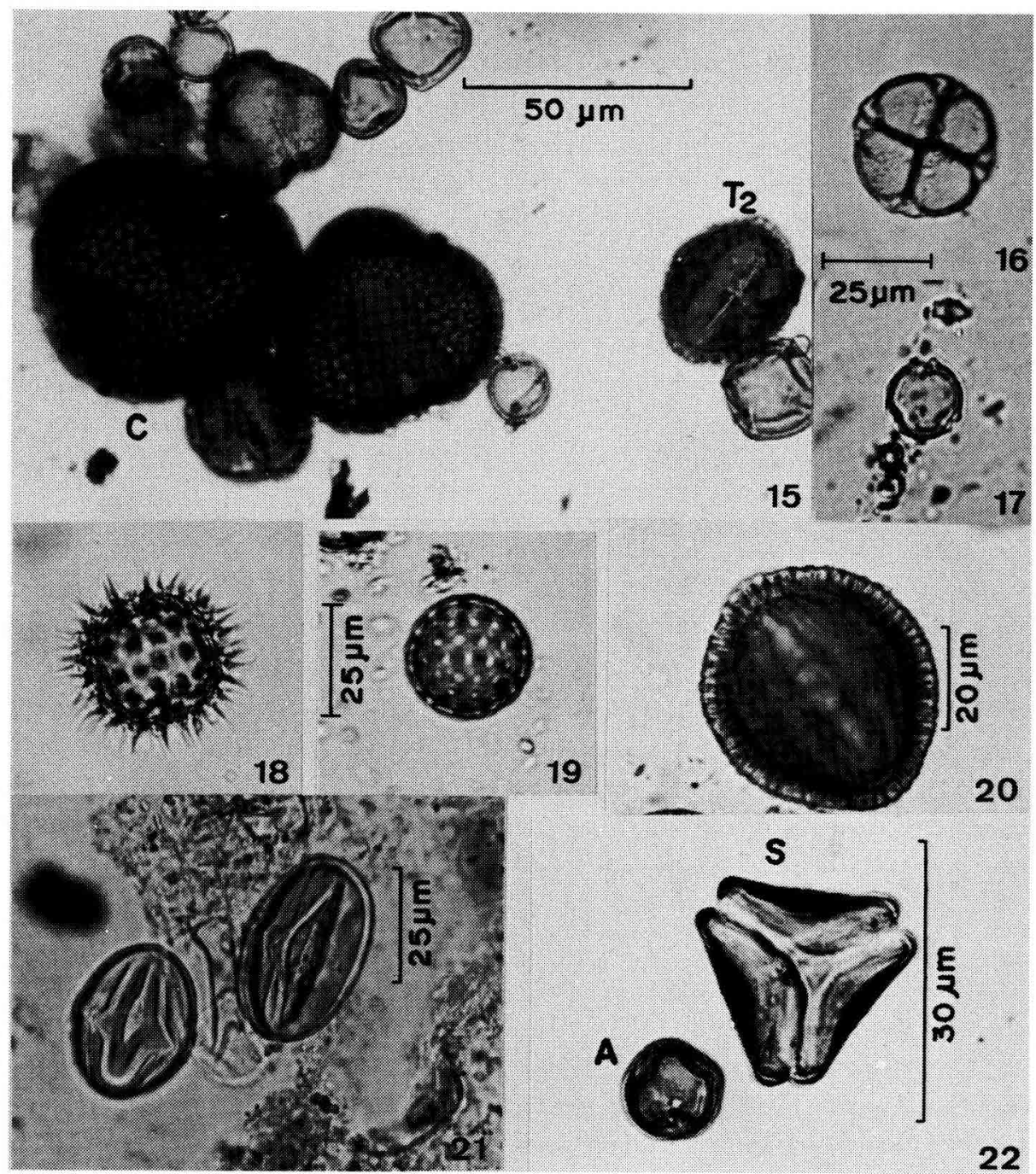

FIG. 15-22. - Photomicrographs of the pollen grains present in the honey of $\mathrm{T}$. angustula.

FIG. 15 : Caesalpinia peltophoroides (C); Tipo 2 (T 2); FIG. 16 : Mimosa daleoides; Fig. 17 : Byrsonima intermedia; FIG. 18 : Bidens sp; FIG. 19 : Chenopodium sp; Fig. 20 : Euphorbia pulcherrima; Fig. 21 : Tipuana tipu; FIG. 22 : Alchornia triplinervia (A), Struthanthus andrastylus (S).

result. This author found, in 5 grams of honey, pollen of 22 plant species, numbering in all 1,000 pollen grains; when using 10 to 20 grams of honey, 28 to 31 species determined in 1,000 pollen grains counted. For Louveaux (1968), the counting of at least 200 pollen grains is sufficient to obtain a valid pollen spectrum and for greater research precision, the number of pollens counted must be multiplied. 
In this work, due to lack of material, 3 to 4 grams of honey were used; all the pollen grains present in the honey sediment were identified and 500 were counted with a minimum of 11 and a maximum of 22 plant species.

Even though the honeys from colonies A and B were from different localities, at a distance of about 140 metres from one another (Fig. 1), they presented, with rare exceptions, pollen grains from the same species, and in general with similar peaks. This suggests that these bees were attracted to the same floral supplies.

The rudimentary data on Brazilian bee flora and the lack of greater knowledge of the pollen of our bee-frequented plants cause great difficulties in analysing the pollen spectrum of honey samples, and in the identifying of the botanical species sought by bees (BARTH, 1970 a, b, c, d; SANTOS, 1974).

Another difficulty lays in the fact that pollen grains from the many plant species frequented by $T$. angustula, were note found in the honey samples examined. Probably the bees observed visiting such flowers were from the natural hives in the area. On the other hand, pollen grains not found in the reference material appeared in the honey samples, suggesting either pollen contamination or that the home range of $T$. angustula was greater than the area examined. LINDAUER and KERR (1960) observed that $T$. angustula could not be trained to visit feeders at distances greater thant 10 metres. NogUeIRA-Neto (personal communication), verified that specimens of T. angustula 500 metres from the hive would return to it. This could to a certain extent explain the appearance of those pollen grains which played no part in the reference preparation, since the plants observed were within a range of about 150 metres from the hive.

With the exception of the honey samples from colony B in 06/74 and 10/74, the analysed honeys of $T$. angustula presented a relatively large number of pollen grains, usually with dust particles, cerumen and rarely spores and fungi. The occurrence of few pollen grains in these two samples, could be explained by the presence of honeydew; however the indicators of honeydew such as spores and fungi, were present in minimal quantities. This suggests that the bees might have collected the nectar in extra-floral nectaries or that they might have collected it without coming into contact with the anthers, reaching the nectaries through openings usually made in the corolla by certain bees such as the "irapuá " (Trigona spinipes) for nectar collecting. Or, there again, they might have collected fruit juices or sap from broken branches; DARCHEN and LoUis (1961) stated that stingless bees collect these substances as well as nectar and honeydew.

It had been expected that the honey samples collected from colony A, would have presented a reduced number of pollen grains, since this hive, though rarely, received a supply of additional food; as food was thus available, there would be no need for external collecting of nectar. This was not the case.

In studies made on pollen spectra of Brazilian honey, such as those of BARTH (1970 a, b, c, d, e) and SANTos (1974), the calculated percentages of pollen grains from 
the different species present in the honey were based on numerical reading, as to the species being more or less nectariferous or polliniferous without the application of correction factors. Little or noting is known about this factor in relation to the bee plants of Brazil.

The fact that pollen - yielding species are quantitavely predominant among the different honey samples examined, does not mean that they should be classified as dominant pollens. For example, Euphorbia splendens, which was present in $100 \%$ of the analysed samples, occurred only once as accessory pollen and mostly as isolated pollen. Phyllanthus sp. was predominant in the samples, but always as isolated pollen. Schinus terebinthifolius, Alchornia triplinervia, Eucalyptus cinerea, E. robusta and Petroselinum hortense, apart from being predominant, were also classified as dominant, accessory and isolated pollen.

The majority of the pollen grains from the samples analysed were classified as isolated pollen, followed by accessory pollen and then dominant pollen. BARTH $(1970 \mathrm{~d})$ observed that this class of pollen grains (I.P.) characterizes the samples of Brazilian honey.

Dominant pollen is very important - as much so as the quantity of nectar supplied - for the elaboration of honey. Among the few plant species considered as dominant pollen yielders are cited: Alchornia triplinervia, Eucalyptus cinerea, E. robusta, Eucalyptus sp., Petroselinum hortense and Schinus terebinthifolius.

Among these plants $A$. triplinervia is not indicated as melliferous, but $A$. iricurana was cited as being a nectar producer with a sugar concentration which reaches $40 \%$ (GIORGINI and GuSMAN, 1972). This concentration is in turn considered as very good for attracting bees. It might be suggested that $A$. triplinervia is very significant as a nectar supply, even though its pollen grains are super-represented, that is, presenting an elevated number in relation to the quantity of nectar which the plant can produce.

As to the genus Eucalyptus, apart from E. cinerea and E. robusta, E. blakelyi, E. rudis and E. tereticornis were identified. KERR and AMARAL (1957) determined that $E$. robusta and $E$. tereticornis are melliferous and present a relatively high sugar concentration, of $51 \%$ and from 30 to $40 \%$ respectively.

SANTOS $(1961,1964,1974)$ and BARTH $(1970 \mathrm{c})$ found pollen grains of nonidentified species of the genus Eucalyptus, to be most frequent in the honey samples of A. mellifera.

Though $E$. cinerea and $E$. robusta have been frequent in the samples studied, and classified as dominant pollen and principally as accessory pollen, it cannot be affirmed that there was an occurrence of nectar predominance of these species in the elaboration of honey.

BARTH (1970 a) and SANTos (1974) observed that the genus Eucalyptus is often super-represented in relation to the nectar supplied, being an excellent producer of pollen grains. For NogueIRA-Neto (1953), the Eucalyptus, apart from producing 
abundant nectar, can offer nesting places for the Meliponine bees in old hollow trees. Ros (1952) apart from E. robusta and E. tereticornis, cited E. botryoides, E. citrioides, E. rostrata, etc., as being good nectar producers. The different species of this plant genus flourish at different times throughout the year, and so constitute an excellent foraging plant for bees (ANDRADE, 1939).

The genus Petroselinum hortense, is indicated as apicultural (GIORGINI and GuSMaN, 1972). For Juliano (1972), Schinus terebinthifolius is a pollen and nectar supplier. Pollen grains classified as dominant pollen, with the exception of $P$. hortense and $S$. terebinthifolius, also appear as accessory pollen.

The accessory pollen class, like that of the dominant pollen, is very important as a nectar supplier in the elaboration of honey. The honey samples with accessory pollen from one or more plant species were far more numerous than the honeys with dominant pollen, probably owing to the lack of large continuous plantations of apicultural species in the surroundings. The bees collected from the vegetation planted in the locality, which consists of introduced ornamental plants and also of plant varieties from tropical forest and grassland.

Compositae (Bidens sp.); Euphorbiaceae (Euphorbia splendens); Leguminosae (Caesalpinia peltophoroides, Dalbergia sp., Mimosa daleoides, Piptadenia rigida); Malpighiaceae (Byrsonima intermedia); Melastomataceae (Tibouchina chamissoana); Moraceae (Sorocea bonplandii); Myrtaceae (Eucalyptus blakelyi, E. rudis and E. tereticornis); Scrophulariaceae (Paulownia tomentosa); Solanaceae (Solanum sp.) and Ulmaceae (Trema micratha), were found as accessory pollen.

For Giorginı and Gusman (1972) Bidens sp. is polliniferous.

E. splendens was a very frequent species in the honeys examined. This Euphorbiaceae, though not cited as a bee plant, is commonly visited by the jatai ( $T$. angustula) and also by $A$. mellifera and Trigona spinipes, practically throughout the year, principally for nectar collecting. This indicates that this plant species was a good nectar supplier and its pollen grains were probably sub-represented, that is, the species presents a small number of pollen grains. In the first place, there is reference to its being a melliferous species, with a very high sugar concentration, from 47 to more than $50 \%$ (AmARAL, 1953). Secondly, there exists the possibility of there being a case of sub-representation, since its pollen grains are large (Fig. 15). For DEmianowicz (1964), there is a certain correlation between the richness and size of the pollen grains in the honey samples. That is, the smaller the pollen grains are, the richer the honey will be in relation to that species of plant, whereas the larger the pollen grains, the poorer the honey.

The genus Dalbergia was cited as melliferous. Ros (1952) and Amaral (1953) cited the following species respectively, Dalbergia variabilis and D. sisso, as being good nectar producers. 
BARTH (1970 a), analysing honey from $A$. mellifera found the species Mimosa scabrella and $M$. caesalpiniaefolia. The author demonstrated that these species were super-represented; it could also be suggested that the species found in the honey of $T$. angustula, Mimosa daleoides, could also have been super-represented.

Piptadenia rigida supplies nectar and pollen; its sugar concentration in the nectar is good, that is, from 32 to $42 \%$ (Juliano, 1972).

Trema micrantha seems to have been important as a nectar supplier. The percentage of these pollen grains was close to that of accessory pollen. BARTH $(1970 \mathrm{c})$ also indicated this plant as apicultural, and classified it as isolated pollen.

The plant species with pollen grains classified as isolated pollen are not important as nectar suppliers, with the exception of those species sub-represented as to the number of pollen grains and which are excellent nectar suppliers; they are important as indicators of regional provenance of honey (BARTH, $1970 \mathrm{a}$ ).

From the results obtained, it can be suggested that the isolated pollen grains of the samples studied were significantly important as a nectar supply for the elaboration of the honey, especially in colony B, since about $50 \%$ of its samples presented a predominance of isolated pollen; and in those which presented accessory pollen, it amounted to aproximately $30 \%$ of the total pollen.

Pollen grains classified as isolated pollen, found in honey, might be derived from polliniferous plants. The bees after collecting the pollen grains, would be able to contaminate the honey with these plant species. BARTH $(1970 \mathrm{~b})$ cites the families Myrtaceae, Palmae, Gramineae and the genus Mimosa as polliniferous.

Anemophilous plants were also frequently represented in honey samples by isolated pollen. Nectarless anemophilous plants may be visited by bees collecting their pollen grains; these pollen grains in the honey would represent contamination or indicate the presence of honeydew.

Within the class of pollen grains listed as isolated pollen (excluding those which are also presented as dominant and accessory pollen), are cited, for example, the Anacardiaceae (Mangifera indica); Araliaceae (Tetrapanax sp.,); Balsaminaceae (Impatiens sultani); Chenopodiaceae (Chenopodium sp.) Compositae (A mbrosia sp., Mikania sp., Solidago sp., Xanthium sp.); Cruciferae (Brassica campestris); Cyperaceae 1; Euphorbiaceae (Euphorbia pulcherrima, Phyllanthus sp.); Graminae 1; Leguminosae (Leucaena glauca, Tipuana tipu); Loranthaceae (Struthanthus andrastylus) and Oleaceae (Jasminum azoricum).

Mangifera indica has already been cited as a bee plant by Ros (1952) and GroRGINI and GUSMAN (1972). Tetrapanax has not been cited as being melliferous; nevertheless, it has been observed that it is visited by T. angustula, collecting nectar and pollen grains.

Impatiens sultani is visited principally by small stingless bees (NoGUEIRA-NETo, 1953). 
The species of Chenopodium, as also those of Cyperaceae and Gramineae are anemophilous (SHARMA, 1970), and normally found in honey samples.

The Compositae present in various samples always amounted to a low percentage. Ambrosia sp. (Giongini and Gusman, 1972) and Xanthium sp. (Ros, 1952) are polliniferous and the genus Mikania and Solidago, for Juliano (1972) are at the same time, nectariferous and polliniferous.

With reference to Brassica campestris, this species is melliferous and has a sugar concentration of 38 to $46 \%$ (KerR and AmARAL, 1957).

Among the Euphorbiaceae, Euphorbia pulcherrima is nectariferous and polliniferous (Juliano, 1972), and Phyllanthus sp. is nectariferous (GIORGiNi and GuSman, 1972).

Leucaena glauca and Tipuana tipu were cited respectively, as polliniferous and nectariferous by Amaral (1953) and Juliano (1972). These plant species were present in high percentages, which approached the limit of accessory pollen; their pollen grains are large in relation to other melliferous species. For such reasons, these plant species were probably sub-represented and were good nectar suppliers.

Jasminum azoricum was cited as melliferous by Ros (1952).

At the Institute of Biosciences this species was in flower practically the whole year, and was very much visited by $T$. angustula, and other small stingless bees.

Received for publication in April 1979

\section{ACKNOWLEDGMENTS}

The authors would like to thank the Conselho Nacional de Desenvolvimento Cientifico e Tecnologico $(\mathrm{CNPq})$ and the Fundação de Amparo à Pesquisa do Estado de São Paulo (FAPESP) for the valuable financial aid in support of this research; Prof. Ana Maria Giulietti and Prof. Dr. Sylvio Paniz$\mathrm{zA}$, for the botanical identification of the reference material; also, Prof. Alasdair G. Burman for linguistic corrections; the Zoology Department of the Biosciences Institute, São Paulo University, and are particulary indepted to Prof. Dr. Paulo Nogueira-Neto for the encouragement and helpful suggestions during the development of this paper.

\section{RÉSUMÉ \\ LE SPECTRE POLLINIQUE DU MIEL DE TETRAGONISCA ANGUSTULA \\ ANGUSTULA LATREILLE (APIDAE, MELIPONINAE)}

L'analyse au microscope de 23 échantillons de miel révèle la présence d'un nombre assez grand de formes polliniques : 55 au total. L'analyse du spectre pollinique du miel récolté par les 2 colonies étudiées montre que les abeilles sont attirées par les mêmes fleurs, bien que les ruches soient situćes en 2 lieux distants l'un de l'autre de $140 \mathrm{~m}$. La majorité des grains de pollen est classée dans la catégorie "pollens iso lés ". La catégorie "pollens dominants" comprend: Alchornia triplinervia, Eucalyptus robusta, Petroselinum hortense et Schinus terebinthifolius. Les pollens de Bidens sp., Byrsonima intermedia, Caesalpinia peltophoroides, Dalbergia sp., Eucalyptus rudis, E. tereticornis, Euphorbia splendens, Mimosa daleoides, 
Piptadenia rigida, Sorocea bonplandii et Trema micrantha sont considérés comme accessoires. Parmi les pollens isolés on trouve : Ambrosia sp., Brassica campestris, Chenopodium sp., Jasminum azoricum. Leu caena glauca, Mangifera indica, Phyllantus sp., Struthanthus andrastylus, Tpuana tipu, etc.

\section{ZUSAMMENFASSUNG}

\section{DAS POLLENSPEKTRUM DES HONIGS VON TETRAGONISCA ANGUSTULA ANGUSTULA LATREILLE (APIDAE, MELIPONINAE)}

Die Pollenanalyse in Honigproben von dieser stachellosen Biene zeigte eine ziemlich grosse Anzahl verschiedener Pollenformen : 55 insgesamt, aus 23 Proben.

Aus der Analyse des Pollenspektrums der Honige der beiden untersuchten Völker ging hervor, dass die Bienen aus diesen Völkern von denselben Blüten angelockt wurden, obwohl sie an verschiedenen, $140 \mathrm{~m}$ voneinander entfernten Plätzen aufgestellt waren.

Die meisten Pollentypen wurden als Einzelpollen klassifiziert. In der Gruppe des Leitpollens fanden sich Alchornia triplinervia, Eucalyptus robusta, Petroselinum hortense und Schinus terebinthifolius.

Als Begleitpollen wurden Bidens sp., Byrsonima intermedia, Caesalpinia peltophoroides, Dalbergia sp., Eucalyptus rudis, E. tereticornis, Euphorbia splendens, Mimosa daleoides, Piptadenia rigida, Sorocea bonplandii, Trema micrantha festgestellt.

Unter den Einzelpollen fanden sich Ambrosia sp., Brassica campestris, Chenopodium sp., Jasminum azoricum, Leucaena glauca, Mangifera indica, Phyllanthus sp., Struthanthus andrastylus, Tipuana tipu und andere.

\section{REFERENCES}

Amaral E., 1953. - Estudos apicolas em leguminosas. Thesis. Escola Superior de Agricultura «Luiz de Queiroz ", Piracicaba, São Paulo, $60 \mathrm{p}$.

Amaral E., 1970. - Flora apicula paulista. Florianópolis. Anais do Congresso Brasileiro de Apicultura, 1, 61-68.

ANdrade E. N., 1939. - O eucalipto. São Paulo, Chácaras e Quintais, 53.55.

BARTH O. M., 1970 a. - Análise microscópica de algumas amostras de mel; 1, pólen dominante. Anais Acad. bras. Cienc., 42 (2), 351-366.

BARTH O. M., 1970 b. - Análise microscópica de algumas amostras de mel; 2, pólen acessório. Anais Acad. bras. Cienc., 42 (3) : 571-590.

Barth O. M., 1970 c. - Análise microscópica de algumas amostras de mel; 3, pólen isolado. Anais Acad. bras. Cienc., 42 (4) : 748-772.

BARTh O. M., $1970 \mathrm{~d}$. - Análise microscópica de algumas amostras de mel; 4, espectro polinico de algumas amostras de mel do Estado do Rio de Janeiro. Rev. bras. Biol., 30 (4), 575-582.

BARTh O. M., 1970 e. - Analise microscópica de algumas amostras de mel; 5, Melato (“ honeydew ") em mel de abelhas. Rev, bras. Biol., 30 (4) : 601-708.

BARTH O. M., 1971. - Análise microscópica de algumas amostras de mel; 6, Espectro polinico de algumas amostras de mel dos Estados da Bahia e do Ceará. Rev. bras. Biol., 31 (4), $431-434$.

CAMpêlo C. R., 1972. - Estudo das plantas néctar-poliníferas (Apícolas) na Baixada fluminense. Garanhuns. Anais do Congresso Nacional de Botânica, 23, 293-298.

DARChen R., Louis J., 1961. - Les mélipones et leur élevage Melipona - Trigona - Lestremelitta. Annl. A beille, 4 (1), 5-39.

Demianowicz Z,, 1964. - Charakteristik der 'Einartenhonige. Annl. Abeille, 7 (4), 273-288. 
ERdtman G., 1960. - The acetolysis method. sv. bot. Tidskr., 54 (4), 561-564.

Giorgini J. F., Gusman A. B., 1972. - A importância das abelhas na polinização. In : CAmArgo, J.M.F. Manual de Apicultura. São Paulo. Ed. Agronômica Ceres, p. 155-214.

Julıano J.C., 1972. - Identificação de espécies de interesse apicola da flora do Rio Grande do Sul. Sete Lagoas. Anais do Congresso Brasileiro de Apicultura, 2, 85-118.

KerR W. E., 1972. - Mais algumas plantas apícolas de São Paulo. Sete Lagoas. Anais do Congresso Brasileiro de Apicultura, 2, 83-84.

Kerr W. E., Amaral E., 1957. - Factores para o aumento da produção de mel no Estado de São Paulo. Solo, 49 (1), 61-69.

Lindauer M., KerR W. E., 1960. - Communication between the workers of stinglessbees. Bee Wld., 41, 29-41, 65-71.

Louveaux J., 1968. - L'analyse pollinique des miels. In : Chauvin R., Traité de biologie de l'abeille. Paris, Masson, V. 3, p. 325-362.

Louveaux J., Maurizio A., Vorwohl G., 1970. - Commission Internationale de Botanique Apicole de l'U.I.S.B. les méthodes de la mélisso-palynologie. Apidologie, Paris, 1 (2), 211-227.

Maurizio A., 1975. - Microscopy of honey. In : Crane E., Honey : a comprehensive survey. London, Heinemann, p. 240-257.

Nogueira-Neto P., 1953. - A criação de abelhas indigenas sem ferrão, 1. ed. Chacaras e Quintais; $280 \mathrm{p}$.

Nogueira-Neto P., 1970. - A criação de abelhas indigenas sem ferrão. 2. ed. São Paulo. Chacaras e Quintais, 365 p.

Ros G. S. O., 1952. - Flora apicola de la America tropical. Cuba, Editorial Lex, 334 p.

Santos C. F. O., 1961. - Morfologia e valor taxonômico do pólen das principais plantas apicolas. Thesis. Escola Superior de Agricultura “Luiz de Queiroz ", Piracicaba, São Paulo, 92 p.

SANTos C. F. O., 1964. - Avaliaçaõ do florescimento das plantas apicolas no ano de 1960, através do pólen contido nos méis e dos coletados pelas abelhas (Apis mellifera). Anais Esc. sup. Agric. "Luiz de Queiroz ", 253-264.

Santos C.F.O., 1974. - Análise polínica de alguns meis do Estado de São Paulo. Piracicaba. Anais do Congresso Brasileiro de Apicultura, 3, 273-278.

Sharma M., 1970. - An analysis of pollen loads of honey bees from Kangra, India. Grana, 10 (1), $35-42$.

Sмiтн F. G., 1965. - The sucrose content of western Australian honey. J. apic. Res., 4 (3), 177-184.

Vergeron Ph., 1964. - Interprétation statistique des résultats en matière d'analyse pollinique des miels. Annl. A beille, 7 (4), 349-364.

VIEITEz E., 1950. - Palynological observations on some Spanish honeys. Bull. Torrey bot. Club., 77 (6), 495-502. 